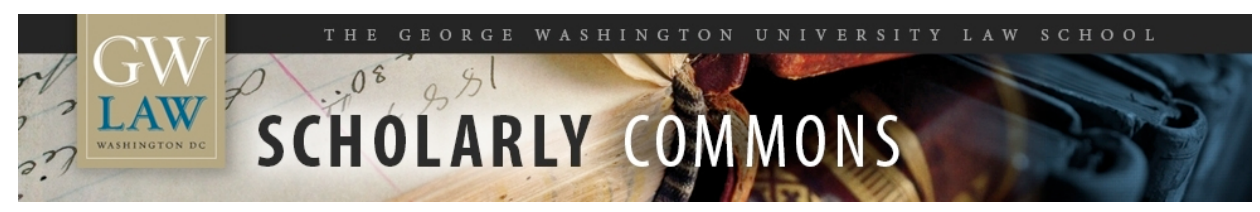

GW Law Faculty Publications \& Other Works

Faculty Scholarship

2002

\title{
The Legal Status of the Doha Declarations
}

Steve Charnovitz

George Washington University Law School, scharnovitz@law.gwu.edu

Follow this and additional works at: https://scholarship.law.gwu.edu/faculty_publications

Part of the Law Commons

\section{Recommended Citation}

Steve Charnovitz, The Legal Status of the Doha Declarations, 5 J. of Int'I Econ. L. 207 (2002).

This Article is brought to you for free and open access by the Faculty Scholarship at Scholarly Commons. It has been accepted for inclusion in GW Law Faculty Publications \& Other Works by an authorized administrator of Scholarly Commons. For more information, please contact spagel@law.gwu.edu. 


\title{
THE LEGAL STATUS OF THE DOHA DECLARATIONS
}

\author{
Steve Chamovitz*
}

The successful conclusion of the WГO Ministerial Conference stands as an important achievement of the trading system. The Doha Conference was not doomed to succeed, and yet did through the dedicated efforts of negotiators from 142 countries. Defining exactly what was achieved is now the subject of some debate. A key issue is the legal status of the two 'Ministerial Declarations' approved at Doha.

One was the Declaration on the TRIPS Agreement and Public Health.' An article in the Wall Streer fotmal explained that 'The declaration goes far beyond the narrow language favored by drug companies - which wanted the pact to be limited to health pandemics like AIDS. Instead, the deal would allow poor countries to break patents for illnesses ranging from cancer to diabetes to asthma.' An article in the Financial Times reported that the developing countries' 'biggest prize was US backing for an assurance that WTO rules on trade-related aspects of intellectual property (TRIPS) would not enable patent laws to be used to block poor countries' access to essential medical supplies'.' These journalistic descriptions of a 'pact', 'deal', and 'assurance' suggest that an important legal decision was taken at Doha. Yet US Trade Representative Robert Zoellick's announcement points to a different result. Zoellick said that 'The adoption of the landmark political declaration on the TRIPS Agreement and public health is a good example of developed and developing nations advancing common goals by working through issues together'. "If the TRIPS and Health Declaration is merely a 'political declaration', then perhaps it is not a legal decision.

What does it mean if a key result of the Doha Conference is a 'political declaration'? Is that a different and lesser output than should have been wrought? If the TRIPS and Health Declaration is a 'political declaration',

* wiimer, Cetter \& Pickering, Washingter, DC.

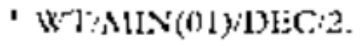

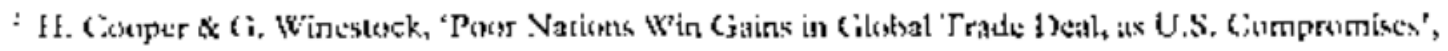

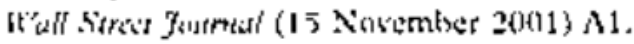

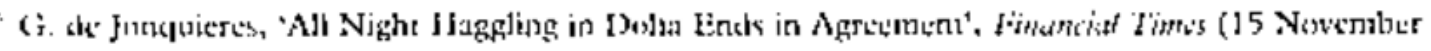
26\%) 11 .

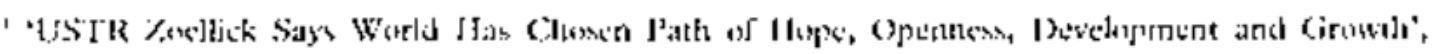

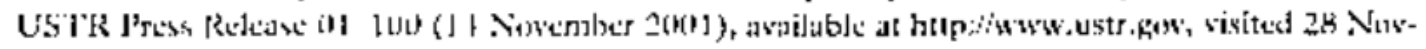
cusber zons. 
does it have a different status than the overall Ministerial Declaration' launching the new WTO work program? Are the two Ministerial Declarations truly 'decisions' of the WTO Ministerial Conference? Or is a 'Declaration' less than a decision? Would it be appropriate for future WTO panels and the Appellate Body to draw guidance from the two new Ministerial Declarations in adjudicating cases? This article will not be able to provide a definitive answer to these questions, but I hope to shed light on them.

\section{WHAT ARE MINISTERLAL DECLARATIONS?}

The Marrakesh Agreement Establishing the World Trade Organization contains several rules on the authority of a Ministerial Conference. Article III:2 states that the WTO provides a forum for 'negotiations among its Members concerning their multilateral trade relations and a framework for the implementation of the results of such negotiations, as may be decided by the Ministerial Conference'. Article IV: 1 states that 'The Ministerial Conference shall have the authority to take decisions on all matters under any of the Multilateral Trade Agreements, if so requested by a Member, in accordance with the specific requirements for decision-making in this Agreement and in the relevant Multilateral Trade Agreement.' Article IX: 1 lays out voting rules for the Ministerial Conference and the General Council.

None of these provisions says anything about a 'declaration' as a legal instrument, but it would seem reasonable that a declaration can be one type of decision. Indeed, the two previous WTO Ministerials adopted Declarations as their main product - Singapore (1997) and Geneva (1998). Yet it may be that not all declarations are necessarily decisions.

A close look at the Doha Ministerial Declarations suggests that they may not be decisions of the Ministerial Conference. One indisputable Decision taken at Doha addressed Implementation-Related Issues and Concerns." This document is subtitled 'Decision' and begins its recital with 'The Ministerial Conference, having regard to Articles IV:1, IV:5 and IX of the Marrakesh Agreement Establishing the World Trade Organization... $\therefore$ Yet a similar recital fails to appear in the Ministerial Declaration launching the round or in the Ministerial Declaration on intellectual property rights and health. Neither of these declarations begins with the words 'The Ministerial Conference'. Some observers have suggested that this omission means that the Doha Ministerial Declarations are not acts of the Ministerial Conference and were not adopted pursuant to the specific authorities of the Marrakesh Agreement.

A contrary view appears in the transcript of the closing session of the Doha Conference, as posted on the WTO website. According to this transcript, Doha Conference Chair Youssef HIussain Kamal, who is Qatar's Minister of Finance, Economy, and Trade, announced to the Conference at the closing session:

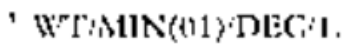

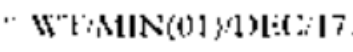


First I should like to propose that the Ministerial Conferencit alupt the draft Ministerial Declaration in document WT/MIN(01)DEC/W/1/. May I take it that this is agreeable to Members? It is so agreed."

A similar parliamentar procedure was used for the TRIPS and Health Declaration. So there would seem to be strong evidence that the Declarations are legal acts of the Doha Ministerial Conference.

Certainly, the Doha Declarations read like official decisions. The TRIPS and Health Declaration delivers two instructions to the Council for TRIPS. The overall Deciaration also instructs that Council and, in addition, gives instructions to the Committee on Trade and Environment (three times), the Gencral Council (five times), the WГO Secretariat (twice), the Director-General (threc times), the Committee on Budget, Finance and Administration, the WTO Subcommittee for I-east-developed Countries, and the Committe on Trade and Development. Morenver, the Declaration states that it "incorporates both an expanded negotiating agenda and wher important decisions and activities necessany to address the chalienges facing the multilateral trading system'."

\section{IMPLICATIONS OF DOHA DECLARATIONS}

The question of the status of the Doha Declarations has significance because they contain many statements to which Members might scek to give legal effect. For example:

We agree that the "lRll'S Agreement does not and should not prevent Members from taking measures to protect public health. Accordingly, while reiterating our commitment to the TRI'S Agrement, we aftirm that the Agrement can and should be interpreted and implemented in a manner supportive of WTO Members' right to protect public health and, in particular, to promote access to medicines for all."

We also agree that the least-developed country Members will not be obliged, with respect to pharmaceutical products, to implement or apply Sections 5 and 7 of Part II of the JTRIPS Agreement or to enforct rights provided for under these Sections until 1 January $2016 .$. .."

We strongly reaffirm our commitment to the objective of sustainable development, as stated in the Preamble to the Martakesh Agrwment. W' are convinced that the aims of upholding and safeguarding an open and non-

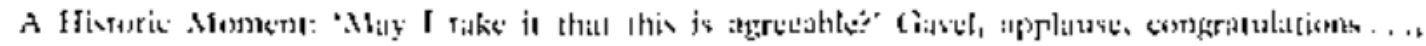

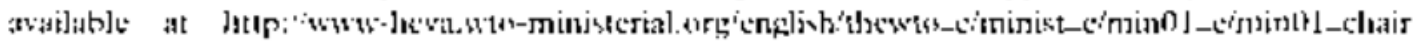

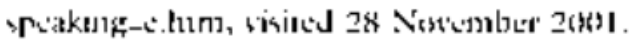

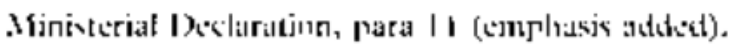

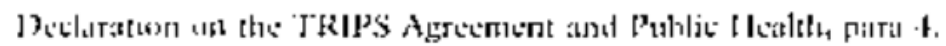

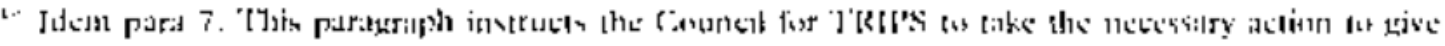

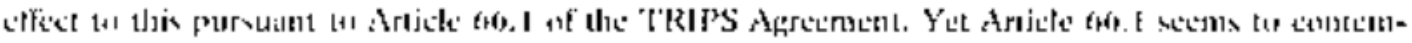

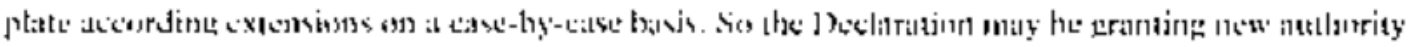
w the coumcil fir tho] 


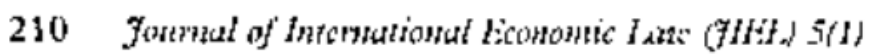

discriminatory multilateral trading system, and acting for the protection of the environment and the promotion of sustainable development can and must be mutually supportive. ${ }^{11}$

We reaffirm the right of Members under the General Agreement on T'rade in Services to regulate, and to intruduce new regulations on, the supply of

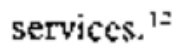

We declare that Members will maintain their current practice of not inposing customs duties on electrunic transmissions until the Fifth Session."

The wording in these paragtaphs, and many others, was very carefully negotiated by the govemments over six days in Doha. Do such tortuous trade talks suggest that governments intended these statements to have an impact on the future operation of the WTO? Presumably so.

If the Doha Declarations are to be categorized as Ministerial Conference decisions, we should be able to cite the authority under which they were adopted. Certainly, the Declarations are not interpretations pursuant to Article IX:2; the governments showed no evidence of using that provision. Perhaps the best explanation is that the Declarations were adopted pursuant to Article III: 2 in order to implement the negotiations at Doha, and pursuant to Article IV:1. These two miles would seem sufficient to authorize a Ministerial Conference decision that launches new negotiations, sets timetables for those negotiations, and approves what is now being called the Doha Development Agenda.

In declining to use its authority to consider WTO amendments (Article X) or to adept interpretations (Article IX:2), the Ministerial Conference was apparently not seeking to change the obligations of Member governments. Thus, the Doha Declarations do not add to or diminish legal obligations. The question to be considered is whether there is flexibility within the WTO legal regime for binding legislative decisions that do not change obligations. We know that the WTO juridical system regularly elucidates legal obligations that do not add to or dininish the rights and obligations of Members. ${ }^{1+}$ But that is a different matter than whether the Ministerial Conference can author such decisions.

One might posit that the Ministerial Conference would be able to craft legal - as opposed to merely political - decisions that do not diminish the obligations of Members. For example, a decision to agree to new negotiations - a commitment stated six times in the main Doha Declaration - could be a legal decision. It would also be possible for the Ministerial Conference to act to fill in a lacunac of WTO law. For instance, a hypothetical decision to establish a procedure for considering anicus curiae briefs would not have altered the obligations of WГO governments. The thesis that Ministerial

" Minivterial Declaratiute, purs 6.

1: Jdent gilra 7.

11 Idیre para 31.

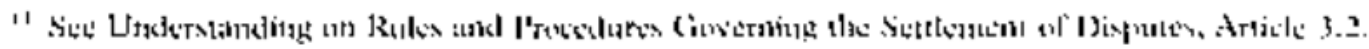


Conference decisions can be legally binding is enhanced when decisions are taken by consensus, as they were at Doba.

In suggesting that the Doha Declarations may qualify as legal decisions, I am not contending that every commitment in them is adjudjcable in WTO dispute settlement. Some commitments in the Declarations are obviousty hortatory. Consider: "We encourage efforts to promote cooperation between the WTO and relevant international environmental and developmental organizations . . $\therefore{ }^{15}$ Hortatory commitments are also present in WTO agreements.

Nevertheless, some commitments in the Declaration might be relevant in a dispute settlement context. While a Ministerial Conference's pronouncement is not treaty language or a treaty interpretation, it might be a subsequent agreement between the parties regarding 'the application' of a treaty's provisions, which is recognized by the Vienna Convention on the Law of Treaties, Article 31.3(a), as a proper consideration in treaty interpretation. In at least one Report, the Appellate Body has taken note of a Decision by a WTO Committee. This occurred in the Shrimp/Turtle dispute when the Appellate Body quoted from the Report of the Committee on Trade and Environment which also formed part of the General Council's report to the Singapore Conference. ${ }^{16}$ If a decision of a WTO Committec can be useful for interpreting WTO law, then a decision of the Ministerial Conference should perforce be even more useful. The WTO website says that the Ministerial Conference is 'the topmost decision-making body of the WTO'.

Some analysts have suggested that the Doha Declarations might be an 'Understanding' akin to the six GATT-related Understandings that were approved in the Uruguay Round. But these GATT Understandings have a different and clearer legal status in being specifically listed as elements in the transformation from 'GATT 1947' to 'GATT 1994'. Furthermore, neither of the Doha Declarations is termed an 'Understanding'.

\section{CONCLUSION}

The legal status of the Doha Declarations is ambiguous. One possibility is that they are merely political statements or moral commitments of trade ministers. In this view, WTO Declarations are analogous to G-7 Declarations or the recent Malmö Declaration of environmental ministers. The other possibility is that the Doha Declarations are part of the constitutive process of decision-making by the WTO as an organization. In this view, the Ministerial Conference can exercise its constitutional authority to set WTO policy, or perhaps to enact secondary law. The extent to which the Doha Declarations are authotitative will be debated in the months ahead. Can we say that a legislative body has begun to formulate world trade law?

\footnotetext{
"Mirsisterial Declatation, para 6.

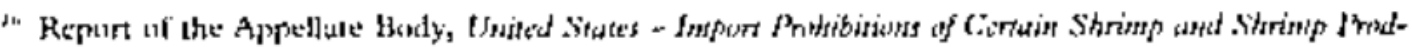

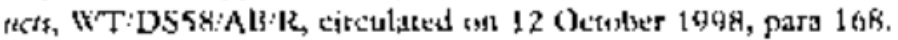

